\title{
Land use change affects biogenic silica pool distribution in a subtropical soil toposequence
}

\author{
Dácil Unzué-Belmonte ${ }^{1, *}$, Yolanda Ameijeiras-Mariño ${ }^{2}$, Sophie Opfergelt ${ }^{2}$, Jean-Thomas Cornelis ${ }^{3}$, Lúcia Barão ${ }^{4}$, \\ Jean Minella ${ }^{5}$, Patrick Meire ${ }^{1}$, and Eric Struyf ${ }^{1}$ \\ ${ }^{1}$ EcosystemManagement Research Group, Department of Biology, University of Antwerp, \\ Universiteitsplein 1C, 2610 Wilrijk, Belgium \\ ${ }^{2}$ Earth and Life Institute, Environmental Sciences, Université catholique de Louvain, \\ Croix du Sud 2 bte L7.05.10, 1348 Louvain-la-Neuve, Belgium \\ ${ }^{3}$ Department Biosystem Engineering (BIOSE), Gembloux Agro-Bio Tech (GxABT), \\ University of Liège (ULg), Avenue Maréchal Juin, 27, 5030 Gembloux, Belgium \\ ${ }^{4}$ ICAAM, Instituto de Ciências Agrárias e Ambientais Mediterrânicas, University of Évora, \\ Apartado 94, 7002-554 Évora, Portugal \\ ${ }^{5}$ Universidade Federal de Santa Maria (UFSM), Department of Soil Science, 1000 Avenue Roraima, \\ Camobi, CEP 97105-900 Santa Maria, RS, Brazil \\ * Invited contribution by Dácil Unzué-Belmonte, recipient of the EGU Soil System Sciences Outstanding Student Poster \\ Award 2014.
}

Correspondence to: Dácil Unzué-Belmonte (dacil.unzuebelmonte@uantwerpen.be)

Received: 21 February 2017 - Discussion started: 27 February 2017

Revised: 11 May 2017 - Accepted: 30 May 2017 - Published: 4 July 2017

\begin{abstract}
Land use change (deforestation) has several negative consequences for the soil system. It is known to increase erosion rates, which affect the distribution of elements in soils. In this context, the crucial nutrient Si has received little attention, especially in a tropical context. Therefore, we studied the effect of land conversion and erosion intensity on the biogenic silica pools in a subtropical soil in the south of Brazil. Biogenic silica (BSi) was determined using a novel alkaline continuous extraction where $\mathrm{Si} / \mathrm{Al}$ ratios of the fractions extracted are used to distinguish BSi and other soluble fractions: $\mathrm{Si}$ / $\mathrm{Al}>5$ for the biogenic AlkExSi (alkalineextractable $\mathrm{Si}$ ) and $\mathrm{Si} / \mathrm{Al}<5$ for the non-biogenic AlkExSi. Our study shows that deforestation can rapidly $(<50$ years) deplete the biogenic AlkExSi pool in soils depending on the slope of the study site (10-53\%), with faster depletion in steeper sites. We show that higher erosion in steeper sites implies increased accumulation of biogenic $\mathrm{Si}$ in deposition zones near the bottom of the slope, where rapid burial can cause removal of BSi from biologically active zones. Our study highlights the interaction of erosion strength and land use for BSi redistribution and depletion in a soil toposequence, with implications for basin-scale Si cycling.
\end{abstract}

\section{Introduction}

The terrestrial $\mathrm{Si}$ cycle has received increased attention in the past two decades. Multiple studies show its complexity, with a strong interaction among primary lithology and weathering, biotic Si uptake, the formation of secondary pedogenic phases and environmental controls such as precipitation, temperature and hydrology (Struyf and Conley, 2012). Lithology controls the primary source of Si through the weathering of silicate minerals of the bedrock (Drever, 1994). This process provides Si to the soil solution in the form of monosilicic acid $\left(\mathrm{H}_{4} \mathrm{SiO}_{4}\right)$, also referred to as dissolved silicon (DSi). This DSi is taken up by plants and is resupplied to the soil in the form of relatively soluble (compared to crystalline silicates) biogenic silicates $(\mathrm{BSi})$ upon plant die-off, usually in the form of phytoliths (plant silica bodies) (Piperno, 2006). Biogenic silica is one of the most soluble forms of Si in soils (e.g., Van Cappellen, 2003), although some pedogenic compounds have similar reactivities (Sauer et al., 2006; Sommer et al., 2006; Vandevenne et al., 2015a). During soil formation, the DSi released to the soil solution through the dissolution of lithogenic and biogenic 


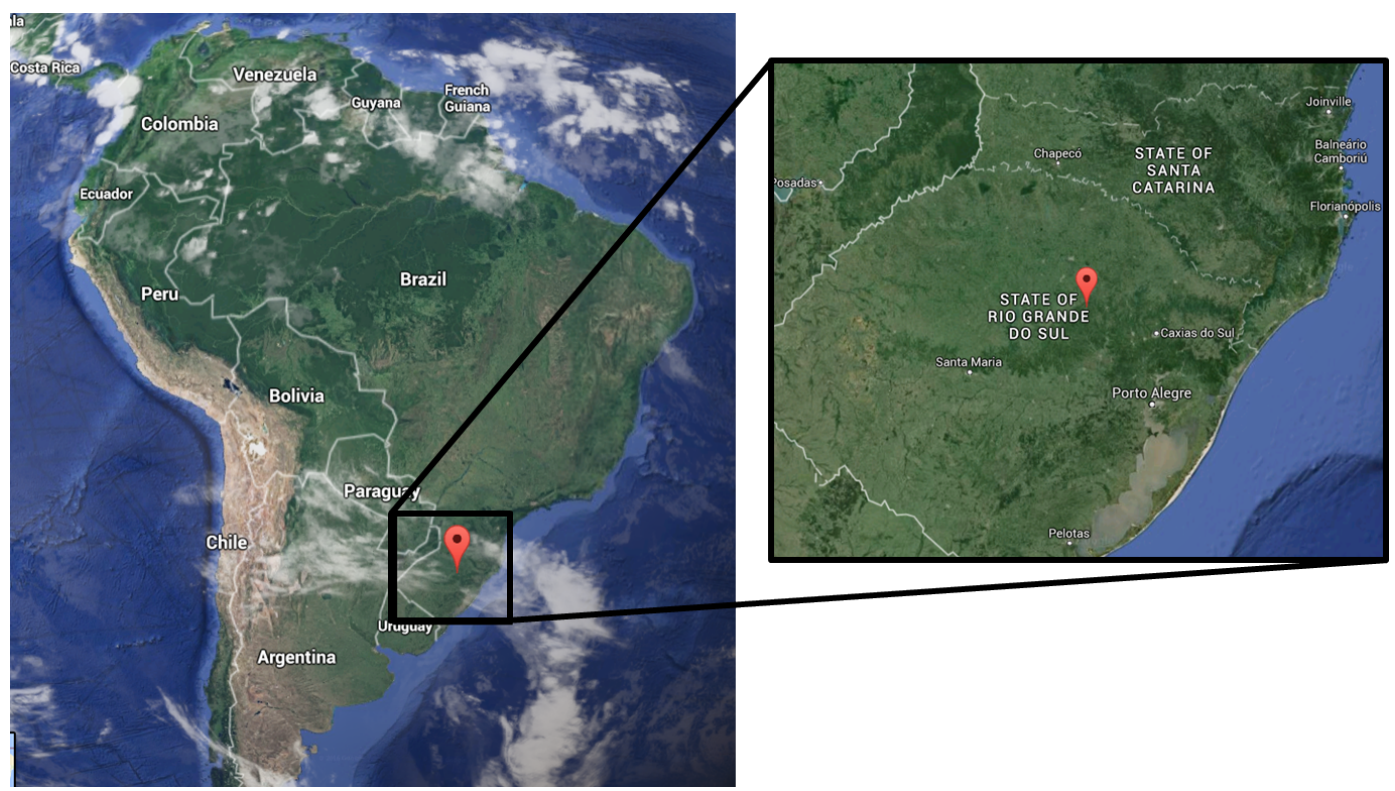

Figure 1. Location of study site.

silicates contributes to the neoformation of pedogenic silicates, i.e., secondary phyllosilicates (Sommer et al., 2006). The biogenic control on the DSi availability in soil increases with weathering degree. Soil mineralogy, strongly governed by geological and climatic conditions, therefore plays a key role in the DSi transfer from soil to plants (Cornelis and Delvaux, 2016). The complex interactions described above, which act to control the Si cycle in terrestrial ecosystems, are often referred to as the "ecosystem Si filter" (Struyf and Conley, 2012), and ultimately determine an important part of the Si fluxes towards rivers.

Land use change is a particularly interesting global change driver to address in this context. Dissolution of soil BSi increases immediately after deforestation (Conley et al., 2008), increasing DSi fluxes out of the soil and the ecosystem. However, in the long term, Struyf et al. (2010) showed a decrease in overall DSi fluxes from cultivated land. The conversion from forest to croplands decreases the soil biogenic Si stock, the most important contributor to the easily available Si pool for plants. The decrease in soil biogenic Si stock has been related to two important factors. The first factor is the harvesting of crops (Guntzer et al., 2012; Meunier et al., 1999; Vandevenne et al., 2012). Harvest prevents the return of plant phytoliths to the soil, depleting the phytolith pool. The resulting decrease in DSi availability also reduces the formation of non-biogenic secondary Si fractions (Barão et al., 2014). A thorough analysis separating both biogenic and non-biogenic fractions is crucial in this regard, since traditional extraction procedures to quantify biogenic Si may also dissolve non-biogenic Si fractions. The second factor affecting BSi losses is erosion. In cultivated catchments, preferential BSi mobilization is associated with erosion during strong rainfall events (Clymans et al., 2015). During such events, biogenic Si can represent up to $40 \%$ of the easily soluble Si inputs to rivers (Smis et al., 2011). Clymans et al. (2015) found that Si mobilization did not depend on tillage technique or crop type but solely on soil loss rate due to erosion.

While it is now accepted that cultivation can cause significant changes in soil $\mathrm{Si}$ pools and $\mathrm{Si}$ fluxes in temperate climates (Keller et al., 2012), the effect of cultivation on (sub)tropical soil Si pools or on soils of volcanic origin is poorly known. Only specific ecosystems, such as rice fields, have been studied (Guntzer et al., 2012) in this regard. Yet, the increasing demand for firewood, timber, pasture and food crops is causing an increase in land conversion to croplands, implying ongoing rapid land degradation in tropical and subtropical forests (Von Braun, 2007; Hall et al., 1993). The aim of our study was to investigate the interactive effects of land use change and terrain slope (as a proxy for erosion) on the distribution of the BSi pool in a subtropical soil system derived from a basaltic parent material. For this purpose, we studied terrestrial Si pools in a natural forest and cultivated land, in gently and steeply sloped locations, applying a recently developed alkaline extraction technique that permits the biogenic and non-biogenic phases to be distinguished.

\section{Methods}

\subsection{Study area}

The study area is situated near Arvorezinha, in the south of Brazil $\left(28^{\circ} 56^{\prime} \mathrm{S}, 52^{\circ} 6^{\prime} \mathrm{W}\right)$ (Fig. 1). Four sites with identical climatic conditions (warm temperate, fully humid with warm summer, Cfb (Kottek et al., 2006), were selected. An- 


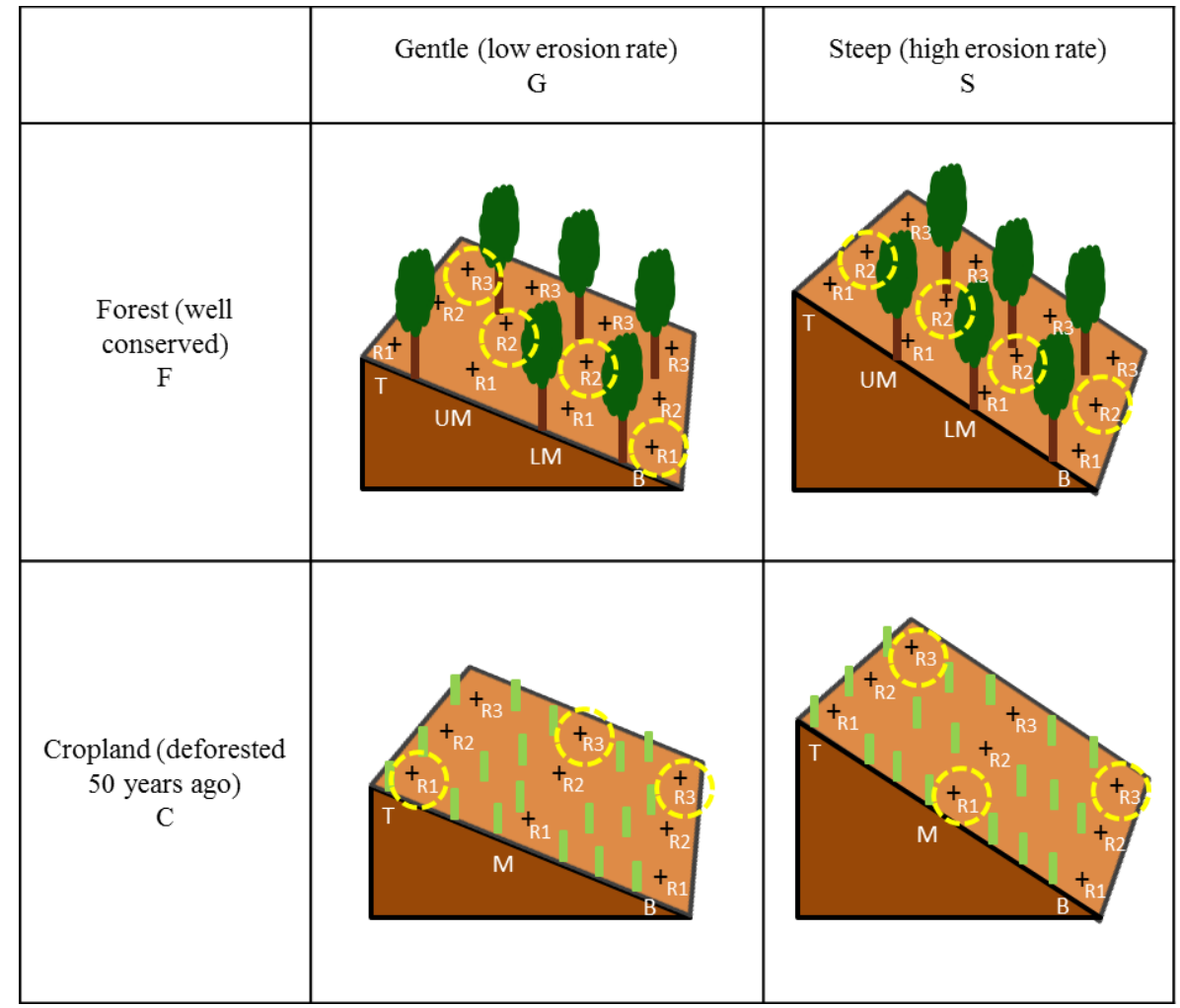

Figure 2. Diagram of the studied sites and the abbreviations used in the text ordered by ecosystem (F: forest; C: cropland), slope (G: gentle; S: steep), position (T: top; UM: upper middle; LM: lower middle; M: middle; B: bottom) and replicate (R1: replicate 1; R2: replicate 2; R3: replicate 3). Plus signs represent sampling points and yellow circles the selected pits.

nual mean temperature is between 14 and $18^{\circ} \mathrm{C}$ and annual mean precipitation between 1700 and $1800 \mathrm{~mm}$ (Minella et al., 2014). The four sampling sites also have the same parent material (rhyodacite). The mineralogy was similar in all sites with sanidine and quartz as the main minerals (AmeijeirasMariño, 2017). Soil type corresponded to an Acrisol in three of the sites and a Leptosol (IUSS Working Group WRB, 2015) in the fourth (steep slope of the cropland), with $\mathrm{pH}$ values between 4.7 and 5.9. They represent two land uses, a well-conserved forest and a cropland, and two slope steepnesses (a steep and a gentle slope), resulting in four different factor combinations (see Fig. 2).

The forest site consists of a semi-deciduous forest with Araucaria angustifolia, Luehea divaricata, Nectandra grandiflora and Campomanesia guaviroba as the dominant species. Within the same forest area, two adjacent sites with different slopes were chosen: a gentle slope (maximum $10^{\circ}$ ) and a steeper slope (maximum $18^{\circ}$ ). On the gentle slope, some scattered small patches of yerba mate crop (Ilex paraguariensis) were recently planted ( $<3$ years ago), occupying less than $10 \%$ of the study site. All studied sampling locations were separated at least $5 \mathrm{~m}$ from these mate patches.

The cropland sites were located in two geographically separated areas, $1.4 \mathrm{~km}$ apart. Deforestation occurred around
50 years ago and they have since experienced the same historical agricultural practices. Intensive soil tillage occurred from the time of deforestation to 2003, when a cover cropping and a minimum tillage practice was introduced (Minella et al., 2014). The actual soil tillage is traditional, based on topsoil mixing and making ridges and furrows. Crops in the gently sloping cropland (maximum $7^{\circ}$ ) rotate between soybean (Glycine max) in summer and black oat (Avena sativa) in winter. Some cattle occasionally graze during the vegetative stage, and after the oat is harvested the biomass is left to produce mulch (cover) to soybean seeding based on the notill system. The cropland of the steep slope (maximum $18^{\circ}$ ) rotates between tobacco (Nicotiana sp.) or maize (Zea mays) in summer and fallow or black oat in winter. The winter crop on this slope is also left behind to produce cover for the next crop.

\subsection{Soil sampling}

Bulk soil samples $(n=297)$ were collected during the summer of 2014. In the forest sites, four positions along the slope (from top to bottom) were selected. In the croplands, due to time constraints during the field campaign, only three positions along the slope (from top to bottom) were selected. Three replicate soil pits were dug per position and soil sam- 
ples were collected every $10 \mathrm{~cm}$ (from top to $50 \mathrm{~cm}$ deep) and every $20 \mathrm{~cm}$ (from 50 to $110 \mathrm{~cm}$ deep) (Fig. 2). Deeper depths were sampled every $50 \mathrm{~cm}$ until $200 \mathrm{~cm}$ deep or until the saprolite was reached. At each depth, $10 \mathrm{~cm}$ of soil (around $2 \mathrm{~kg}$ ) was collected. At larger sample intervals, the $10 \mathrm{~cm}$ sample was collected in the middle of the depth interval. Soil samples were mixed, dried $\left(\sim 40^{\circ} \mathrm{C}\right)$, gently crushed and sieved $(2 \mathrm{~mm})$ prior to analysis.

Kopecky ring samples were also collected at each sampled depth. Samples were weighted before and after drying at $105^{\circ} \mathrm{C}$ in order to calculate bulk densities.

\subsection{Analysis}

One pit per position was selected as a representative pit due to the impossibility of carrying out the novel alkaline extraction analyses on such a high number of samples (297), resulting in a total of 81 samples. The selection avoided pits containing large inclusions (visually) or pits shallower than the other two replicas. The abbreviations and selected pits are shown in Fig. 2.

\subsubsection{Physicochemical analyses}

A portion of the bulk samples was crushed and a subsample was heated at 105 and $1000^{\circ} \mathrm{C}$ to obtain the dry weight and the loss on ignition. The total element content was obtained through borate fusion (Chao and Sanzolone, 1992) of another subsample of the crushed sample; $100 \mathrm{mg}$ was fluxed at $1000^{\circ} \mathrm{C}$ for $5 \mathrm{~min}$ in a graphite crucible with $0.4 \mathrm{~g}$ of lithium tetraborate and $1.6 \mathrm{~g}$ of lithium metaborate, then cooled and dissolved in $100 \mathrm{~mL}$ of $2 \mathrm{M}$ $\mathrm{HNO}_{3}$ under magnetic agitation at $90-100^{\circ} \mathrm{C}$. Elemental contents were determined by inductively coupled plasmaatomic emission spectrometry (ICP-AES); the total reserve of bases $(\mathrm{TRB}=[\mathrm{Ca}]+[\mathrm{Mg}]+[\mathrm{K}]+[\mathrm{Na}])$ was calculated afterwards. TRB is commonly used as a weathering index as it estimates the content of weatherable minerals (Herbillon, 1986).

Particle size distribution was executed with a Beckman Coulter device (LSTM-13320) to quantify the sand ( $2 \mathrm{~mm}-$ $50 \mu \mathrm{m})$, silt $(50-2 \mu \mathrm{m})$ and clay $(<2 \mu \mathrm{m})$ fractions.

The mineralogy of sand and silt fractions was determined by powder X-ray diffraction (XRD, Cu Ka, D8). Clay fraction mineralogy was assessed by XRD after $\mathrm{K}^{+}$and $\mathrm{Mg}^{2+}$ saturation, ethylene glycol solvation and thermal treatments at 300 and $550^{\circ} \mathrm{C}$ (Robert and Tessier, 1974).

\subsubsection{Alkaline continuous extraction}

All samples from selected pits $(n=81)$, together with some additional depths from other pits, were analyzed for biogenic and non-biogenic Si content, resulting in a total of 145 bulk soil samples ( 84 on the forest sites and 61 on the croplands). Samples were analyzed in a continuous flow analyzer (Skalar, Breda, the Netherlands), using a continuous alkaline extraction recently adapted for soils by Barão et al. (2014). The extraction in $180 \mathrm{~mL}$ of $0.5 \mathrm{M} \mathrm{NaOH}$, at $85^{\circ} \mathrm{C}$ runs for half an hour. Dissolved Si and dissolved aluminum (Al) are measured continuously (with the spectrophotometric molybdate blue method and the lumogallion fluorescence method, respectively), obtaining two dissolution curves which are fitted with first-order Eq. (1).

$$
\begin{aligned}
& \mathrm{Si}_{t}\left(\mathrm{mgg}^{-1}\right)=\left(\sum_{i=1}^{n} \operatorname{AlkExSi}_{i} \times\left(1-e^{-k_{i} \times t}\right)\right)+b \times t, \\
& \mathrm{Al}_{t}\left(\mathrm{mgg}^{-1}\right)=\left(\sum_{i=1}^{n} \frac{\mathrm{AlkExSi}_{i}}{\mathrm{Si} / \mathrm{Al}_{i}} \times\left(1-e^{-k_{i} \times t}\right)\right)+\frac{b \times t}{\mathrm{Si} / \mathrm{Al}_{\text {min }}},
\end{aligned}
$$

where $\mathrm{Si}_{t}$ and $\mathrm{Al}_{t}$ are the concentrations of $\mathrm{Si}$ and $\mathrm{Al}$, respectively, at any given time. The equations consist of two parts: the mineral fraction, which has a linear dissolution behavior (DeMaster, 1981; Koning et al., 2002), and the fractions exhibiting nonlinear dissolving behavior. For the mineral fraction, the model renders a linear dissolution rate $(b)$ and the $\mathrm{Si} / \mathrm{Al}$ ratio $\left(\mathrm{Si} / \mathrm{Al}_{\min }\right)$ of that linear fraction. Nonlinearly dissolving fractions are characterized by the total amount of Si (alkaline extractable Si (AlkExSi), $\mathrm{mg} \mathrm{g}^{-1}$ dry weight of initial sample mass), the $\mathrm{Si} / \mathrm{Al}$ ratio (concentration of $\mathrm{Si}$ over concentration of $\mathrm{Al}$ ) of that fraction and its dissolution rate $\left(k, \min ^{-1}\right)$. Assuming the same $\mathrm{Si}$ and $\mathrm{Al} \mathrm{re-}$ lease rate from the same compound and relating the $\mathrm{Si}$ and $\mathrm{Al}$ concentration equations through the $\mathrm{Si} / \mathrm{Al}$ ratio, with the three parameters estimated (AlkExSi, $k$ and $\mathrm{Si} / \mathrm{Al}$ ratio) the different fractions dissolving nonlinearly are distinguished. The same model is fitted with one, two or three first-order equations (summation to $n$ in the formula) and the solution showing least error ( $F$ test) from the three fits is kept. For the nonlinear fractions, the $\mathrm{Si} / \mathrm{Al}$ ratio of the fraction is used to determine its origin. Barão et al. (2014) recognized the following fractions: fractions showing a $\mathrm{Si} / \mathrm{Al}$ ratio $>5$ were considered as indicative of a biogenic fraction, as the concentration of $\mathrm{Al}$ in phytoliths is low (Bartoli, 1985; Piperno, 2006). A fraction showing a $\mathrm{Si} / \mathrm{Al}$ ratio $<5$ was considered as representative of non-biogenic or pedogenic Si fractions (clay minerals, oxides and organo-Al complexes). We opted to discard fractions that represent less than $0.1 \mathrm{mg} \mathrm{Si} \mathrm{g}^{-1}$, as they are smaller than or equal to the detection limit of the method (Barão et al., 2015). Fractions with $k<0.1$ were also discarded, as they represent near linearly dissolving fractions.

\subsubsection{Post-data treatments}

AlkExSi pools or stocks every $10 \mathrm{~cm}$ depth $\left(\mathrm{kg} \mathrm{Si} \mathrm{m}^{-2}\right)$ for selected pits were calculated according to Eq. (2).

AlkExSi stock $\left(\mathrm{kg} \mathrm{Si} \mathrm{m}^{-2}\right)=\frac{[\mathrm{AlkExSi}] \times \mathrm{BD} \times h}{100}$,

where [AlkExSi] is the concentration $\left(\mathrm{mg} \mathrm{g}^{-1}\right)$ obtained in the alkaline continuous extraction, BD is the bulk density 
$\left(\mathrm{g} \mathrm{cm}^{-3}\right)$ of that sample, $h$ is the thickness of the depth interval of the sample $(\mathrm{cm})$ and 100 is a conversion factor from $\mathrm{mg} \mathrm{cm}^{-2}$ to $\mathrm{kg} \mathrm{m}^{-2}$. This calculation takes into account the bulk density of each sample, correcting the amount of AlkExSi per gram of dried soil according to the water content at that specific soil depth. It also calculates the amount of AlkExSi in relation to the thickness of the interval collected $(10 \mathrm{~cm})$. For larger intervals, where only $10 \mathrm{~cm}$ was collected at mid-interval depth, values of the non-sampled depths were linearly interpolated between two known values. The result is given in kilograms per square meter, in our case at $10 \mathrm{~cm}$ deep intervals.

In order to estimate the total biogenic and non-biogenic AlkExSi pools per pit, the sum of all $10 \mathrm{~cm}$ depth biogenic and non-biogenic AlkExSi pools of each pit was made.

Once having the biogenic and the non-biogenic AlkExSi pools per pit, averages between the three (for the croplands) or four (for the forests) selected pits were made in order to assign average biogenic and non-biogenic AlkExSi pool values to the slope and to be able to compare AlkExSi pools between different sites. Then, comparisons between the different study sites were made. In order to compare the biogenic and non-biogenic AlkExSi pools from the forests with the croplands, two different methods were considered, taking into consideration that the number of positions along the slope in the forest sites is higher than in the cropland sites (four and three, respectively): Average 1, using all available measurements for the forest (the four positions along the slope) and cropland sites, and Average 2, using a precalculated average between upper and lower middle position measurements in the forest sites.

To study the accumulation of biogenic and non-biogenic AlkExSi pools at the bottom of the slope we have calculated the accumulation (AC) using the pool in the bottom compared to the summed pools along the slope for the forests (Eq. 3) and the croplands (Eq. 4). The closer the AC value is to $100 \%$, the higher the accumulation results.

$$
\begin{aligned}
& \mathrm{AC}_{\text {Forest }}= \\
& \frac{\mathrm{AlkExSi}_{\text {bottom }}}{\mathrm{AlkExSi}_{\text {top }}+\mathrm{AlkExSi}_{\text {upper middle }}+\mathrm{AlkExSi}_{\text {lower middle }}+\mathrm{AlkExSi}_{\text {bottom }}} \times 100,
\end{aligned}
$$

$$
\begin{aligned}
& \mathrm{AC}_{\text {Cropland }}= \\
& \frac{\mathrm{AlkExSi}_{\mathrm{St}-\text { bottom }}}{\mathrm{AlkExSi}_{\text {top }}+\mathrm{AlkExSi}_{\text {middle }}+\mathrm{AlkExSi}_{\text {bottom }}} \times 100 .
\end{aligned}
$$

Statistical differences between biogenic AlkExSi pool averages for top pits, middle slope pits, bottom pits and differences between biogenic AlkExSi pool averages from the top pit and the bottom pit within the same slope were tested pair by pair for significance at the $5 \%$ level confidence using a Student $t$ test assuming unequal variances.

\section{Results}

\subsection{Soil physicochemical characteristics}

Results from total element content, particle size, bulk density and TRB values for selected pits are shown in Tables S2$\mathrm{S} 4$ in the Supplement. The XRD mineralogical analysis of the bedrock (rhyodacitic volcanic rocks) reveals that sanidine (feldspar group) is the most abundant mineral (45-55\%), followed by very fine-grained quartz $(\sim 38 \%)$ embedded in a matrix of hematite, goethite and clays $(\sim 8 \%)$ (AmeijeirasMariño, 2017). Bulk densities of selected pits ranged from 0.7 to $1.54 \mathrm{mg} \mathrm{cm}^{-3}$.

\subsection{AlkExSi concentrations}

AlkExSi values $\left(\mathrm{mg} \mathrm{g}^{-1}\right.$ dried soil) with the corresponding $k$ values and $\mathrm{Si} / \mathrm{Al}$ ratio per fraction are presented in $\mathrm{Ta}$ ble S1. In order to distinguish fractions according to the $\mathrm{Si} / \mathrm{Al}$ ratio, the thresholds applied by Barão et al. (2014) were used: fractions showing $\mathrm{Si} / \mathrm{Al}$ ratios above 5 were considered to be biogenic, and fractions showing $\mathrm{Si} / \mathrm{Al}$ ratios below 5 were considered to be non-biogenic fractions.

Figure 3 shows the concentrations of biogenic $(\mathrm{Si} / \mathrm{Al}>5)$ and non-biogenic AlkExSi fractions $(\mathrm{Si} / \mathrm{Al}<5)$ within the soil profiles of selected pits. Overall, the highest concentrations of biogenic AlkExSi appear in the top of the profiles or near the surface and decrease with depth. Biogenic AlkExSi is also more abundant at the bottom positions of the slopes. On the other hand, non-biogenic AlkExSi fractions are generally absent in the top soil layers and increase in concentration with depth.

\subsection{AlkExSi pools}

The biogenic and non-biogenic AlkExSi pools of selected pits at $10 \mathrm{~cm}$ intervals are presented in Table $\mathrm{S} 5$.

Figure 4 shows the biogenic and non-biogenic AlkExSi pools as a soil profile cut from the top to the bottom of the slope, for the four study sites.

The averages of biogenic and non-biogenic AlkExSi pools per position, land use and slope are shown in Table 1. As mentioned, other averaged AlkExSi pools were calculated when comparing forest to cropland ("Average 2" in Table 1). The pre-calculated average between the upper-middle and lower-middle position was used in the calculation for "Average 2" (Table 1) (i.e., values used for the gentle slope "Average 2" calculation were 16.7 (top), 16.1 (middle) and 6.79 $\mathrm{kg} \mathrm{m}^{-2}$ (bottom)).

While the gentle and the steep slope of the forest showed near-equal biogenic AlkExSi pools $(+10 \%$ for the steep slope), non-biogenic AlkExSi pool might be higher on the steep slope $(+81 \%$ for the steep slope).

In the cropland, results were slightly different. Both AlkExSi pools were higher on the gently sloped cropland 

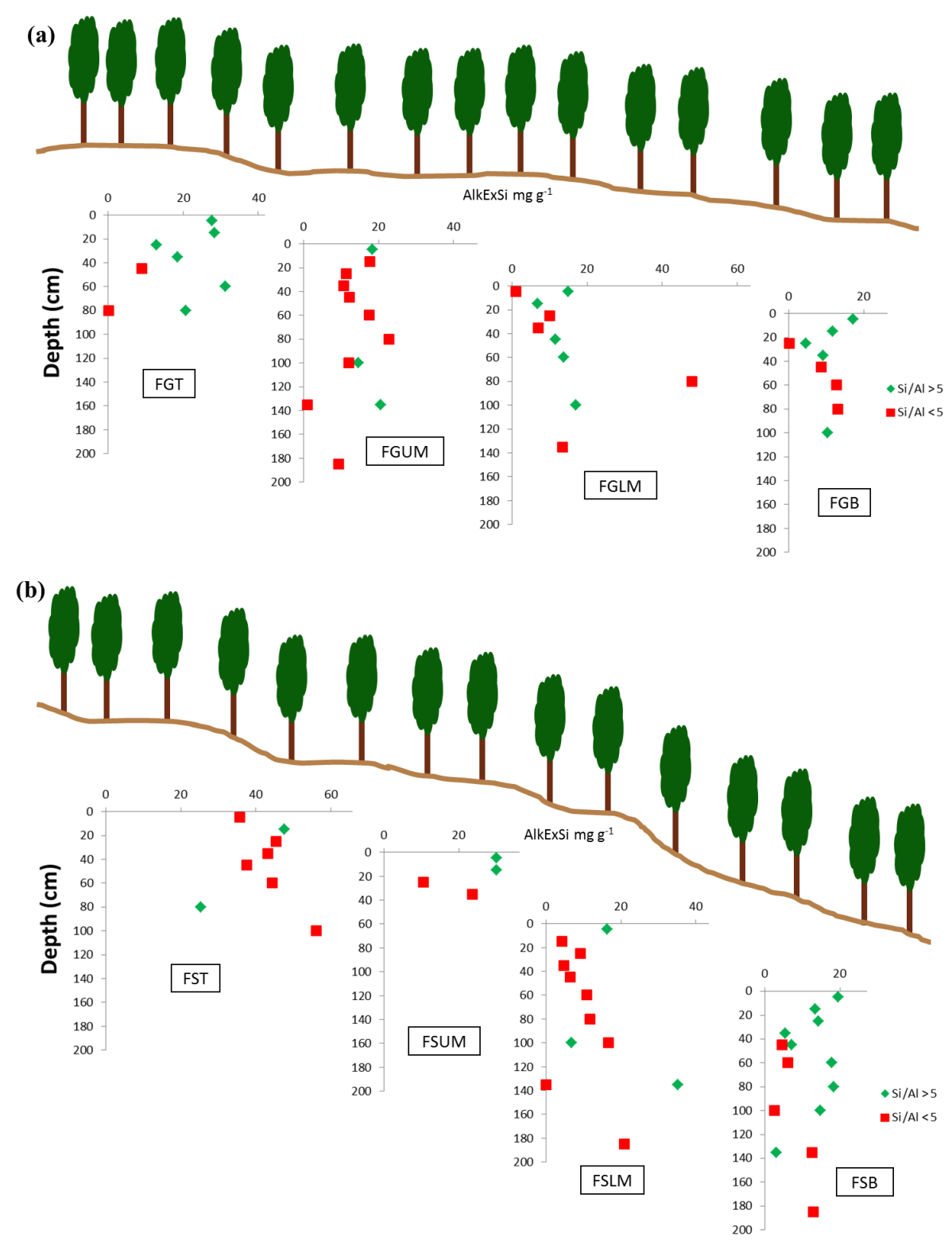

Figure 3.

$(+35 \%$ for the biogenic AlkExSi pool and $+85 \%$ for the non-biogenic AlkExSi pool).

When comparing gently sloped forest and cropland (using "Average 2" for forests), there was only a small difference for biogenic AlkExSi pool ( $-12 \%$ for the cropland), but nonbiogenic AlkExSi might be higher in the cropland $(+57 \%$ for the cropland).

On the steep slopes, it was clear that both AlkExSi pools were much lower in the cropland compared to the forest $(-53 \%$ for the biogenic AlkExSi pool and $-90 \%$ for the non-biogenic AlkExSi pool).

The sum of the AlkExSi pools of selected pits per land use and slope is shown in the Table 1 ("Total (sum)"). The accumulation of the biogenic and non-biogenic AlkExSi pools at the bottom position of each slope is also shown in Table 2 . Both steep slopes clearly showed higher accumulation of both pools at the lowest position than the gentle slopes, with the exception of the non-biogenic AlkExSi pool in the steep slope of the cropland.

Pairs showing significant differences are represented with the same letter in Table 1.

\section{Discussion}

One of the most striking observations in our study is the interaction between slope and land use effect. On the steep slope, there is a decrease in AlkExSi pools from forest to cropland. 
(c)

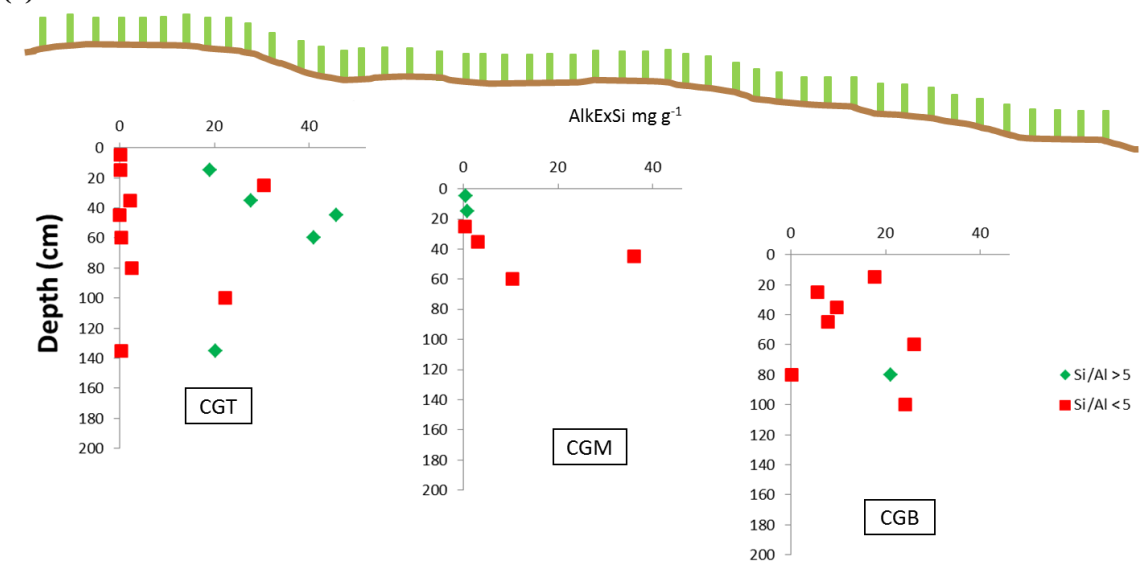

(d)

Figure 3. Biogenic and non-biogenic AlkExSi concentrations $\left(\mathrm{mg} \mathrm{g}^{-1}\right.$ dried soil) from selected pits of the sites studied: (a) gentle slope of the forest, (b) steep slope of the forest, (c) gentle slope of the cropland and (d) steep slope of the cropland. Graphs from left to right: top, upper middle, lower middle (or middle) and bottom pit.

In contrast, the gentle slopes had similar biogenic AlkExSi pools. It is also clear that there is redistribution of biogenic AlkExSi towards the bottom positions of the slope on steeply sloped croplands and forests.

\subsection{Redistribution of AlkExSi concentrations in depth and along the toposequence}

In general, the distribution of biogenic AlkExSi shows the same pattern within each pit: the concentration decreases with depth and highest concentrations are found at the bottom of the slope (with the exception of the gentle slope of the cropland). This agrees with earlier observations on the distribution of BSi along a toposequence in several soil catenas from temperate areas (Saccone et al., 2007). The distribution of non-biogenic AlkExSi shows a complementary pattern. Non-biogenic AlkExSi fractions are rarely present at the top of the profiles but higher concentrations are found in deeper layers. Similar patterns were reported in a study carried out in arkosic sediment soils in California (Kendrick and Graham, 2004) and for temperate Luvisols in Belgium and Sweden (Barão et al., 2014; Vandevenne et al., 2015a). Upon leaching of DSi after BSi dissolution, the DSi infiltrates and reacts to form, for example, secondary clays. It can also be adsorbed onto oxides. The rate of adsorption of DSi by oxides is determined by water infiltration rate, $\mathrm{pH}$, water residence time and weathering intensity (Cornelis et al., 2011; Jones and Handreck, 1963). A large amount of oxides in soil (see "Mineralogy" in Table S4), high DSi supply, strong water infiltration rates and high $\mathrm{pH}$ may result in larger concentrations of $\mathrm{Si}$ absorbed by oxides. Our studied sites satisfy these conditions with the exception of the $\mathrm{pH}$ (4.7-5.9). Uehara and Gillman (1981) suggested that weathered soil systems can result in a desilicated soil enriched in $\mathrm{Fe}$ and $\mathrm{Al}$ oxides, with $\mathrm{pH}$ close to neutral values. Similar 
Table 1. Biogenic and non-biogenic AlkExSi pools $\left(\mathrm{kg} \mathrm{Si} \mathrm{m}^{-2}\right)$, of the selected pits, for the two ecosystems (forest, cropland), for the different slopes (gentle, steep), along different positions along the slope (top, upper middle, lower middle and bottom). Total (sum), Average 1 (averaged pool between all selected pits) and Average 2 (for the forest sites: averaged pool between top, pre-calculated average between the upper-middle and the lower-middle pit (i.e., for the biogenic AlkExSi pool of FG: $16.1 \mathrm{~kg} \mathrm{Si} \mathrm{m}^{-2}$ ) and bottom pits) of biogenic and nonbiogenic AlkExSi pools per site. Accumulation of the biogenic and non-biogenic AlkExSi pools (see Eqs. 3 and 4).

\begin{tabular}{|c|c|c|c|c|c|c|c|c|}
\hline & \multicolumn{4}{|c|}{ Forest } & \multicolumn{4}{|c|}{ Cropland } \\
\hline & \multicolumn{2}{|c|}{ Gentle } & \multicolumn{2}{|c|}{ Steep } & \multicolumn{2}{|c|}{ Gentle } & \multicolumn{2}{|c|}{ Steep } \\
\hline & Biogenic & Non-biogenic & Biogenic & Non-biogenic & Biogenic & Non-biogenic & Biogenic & Non-biogenic \\
\hline Top & $17.6^{\mathrm{a}}$ & 1.32 & 9.06 & 31.0 & $30.7^{\mathrm{b}}$ & 15.0 & $7.50^{\mathrm{ab}}$ & 3.25 \\
\hline Upper middle & $19.3^{* * a b}$ & 22.1 & $6.98^{* * \mathrm{~cd}}$ & 3.98 & $0.21^{\mathrm{ad}}$ & 8.50 & $0.43^{\mathrm{bc}}$ & 0.93 \\
\hline Lower middle & 12.9 & 10.3 & 25.8 & 25.7 & & & & \\
\hline Bottom & $6.79^{\mathrm{ab}}$ & 7.63 & $24.8^{\mathrm{ac}}$ & 20.3 & $5.38^{\mathrm{cd}}$ & 16.0 & $15.8^{\mathrm{bd}}$ & 0.80 \\
\hline Total (sum) & 56.6 & 41.3 & 66.6 & 81.0 & 36.3 & 39.5 & 23.8 & 4.97 \\
\hline Average 1 & $14.2 \pm 5$ & $10.3 \pm 7.6$ & $16.6 \pm 8.7$ & $20.3 \pm 10$ & $12.1 \pm 13$ & $13.2 \pm 3.3$ & $7.92 \pm 6.3$ & $1.66 \pm 1$ \\
\hline Average 2 & $13.5 \pm 5$ & $8.4 \pm 6.1$ & $16.7 \pm 6$ & $22.1 \pm 6.7$ & & & & \\
\hline Accumulation & $12 \% *$ & $18 \%$ & $37 \%$ & $25 \%$ & $15 \% *$ & $41 \%$ & $67 \% *$ & $16 \%$ \\
\hline
\end{tabular}

$\mathrm{a}, \mathrm{b}, \mathrm{c}, \mathrm{d}$ Averages by row showing the same letter are statistically different $(p<0.005) .{ }^{*}$ Difference between the top and the bottom pit averages from that slope is statistically significant $(p<0.005)$. ${ }^{* *}$ Statistical comparison between middle position between forest sites and cropland sites were calculated taking the two middle pits (upper and lower middle) for the forests.

processes might occur in our soils, although they are not desilicated, but do show a high weathering intensity.

Biogenic $\mathrm{Si}$ concentrations from Vandevenne et al. (2015a) in temperate Luvisols were 1 order of magnitude lower than in our study. The high silica content of the rhyodacite bedrock in our study sites, together with high weathering rates characteristic of tropical and subtropical soils (Drever, 1994), supplies a large amount of DSi to the soil. In addition, weathering stimulated by plants is particularly strong in the tropics (Blecker et al., 2006; Kelly et al., 1998); turnover rates of nutrients are also higher in tropical and subtropical ecosystems than in temperate regions (Alexandre et al., 1997; Derry et al., 2005), due to high water availability and temperature. Meunier et al. (2010) showed that the DSi supply from the dissolution of basalts was 1.8 times higher than the DSi produced from the dissolution of the litter in a Leptosol of La Réunion (Indian Ocean).

\subsection{Effects of erosion and land use change on the biogenic AlkExSi pool along the toposequence}

For cropland, it is well documented that the harvest of crops exports large amounts of BSi from the system. This generates BSi-depleted systems in the long term (e.g., Vandevenne et al. 2015b). Results from Clymans et al. (2011) in long-term croplands from Sweden showed a BSi pool reduction of $10 \%$ compared to a forested system.

Guntzer et al. (2012) showed the importance of crop rotation in the turnover and accumulation of phytoliths in soil. The accumulation of phytoliths is also influenced by the geochemical stability of phytoliths (Song et al., 2012). However, the crops rotating in both fields are different and have different Si demands. Maize and black oat are known to have high Si content, while tobacco and soy do not (Currie and Perry, 2007; Piperno, 2006). The turnover between maize/tobacco and fallow/black oat on the steep slope might be an explanation for the smaller biogenic AlkExSi pool at this site. Moreover, the higher erosion rate increases the biogenic AlkExSi deposition at the bottom of the steeply sloped cropland. In fact, the TRB in this slope was higher than at any of the other sites (the lower the TRB, the more weathered the soil is, or vice versa - the higher the TRB, the closer the soil is to the composition of the bedrock), suggesting that all weathered material has been already eroded and the saprolite is closer to the surface.

It is interesting to note that a redistribution of biogenic AlkExSi occurs along the slope (Fig. 4). A higher slope degree, and thus higher erosion rate, provokes the loss of material through water erosion and tillage (Govers et al., 1996), transporting material downslope and resulting in an accumulation of the biogenic AlkExSi pool at the bottom of the slope. In the gently sloped sample site, biogenic AlkExSi is more stable at the higher positions of the slope, while in the steep slope it accumulates at the bottom.

The biogenic AlkExSi pool in the gentle slope of the forest was $\sim 14 \mathrm{~kg} \mathrm{Si} \mathrm{m}^{-2}$. A high rate of phytolith production in this forest, corresponding to a high Si demand from trees and efficient internal recycling, can maintain the BSi stock of the soil system. Ferrasols in Congolese equatorial forests had a phytolith pool 5 times smaller than the present results (2.66 $\mathrm{kg} \mathrm{m}^{-2}$ in Alexandre et al., 1997) and the amorphous 
(a)

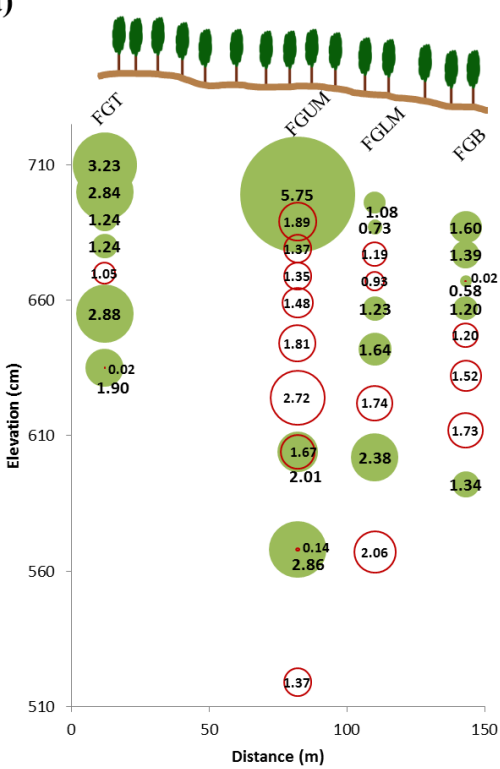

(c)

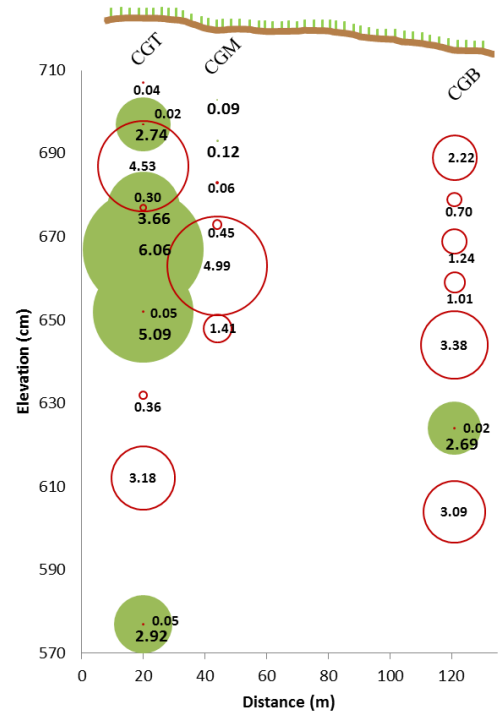

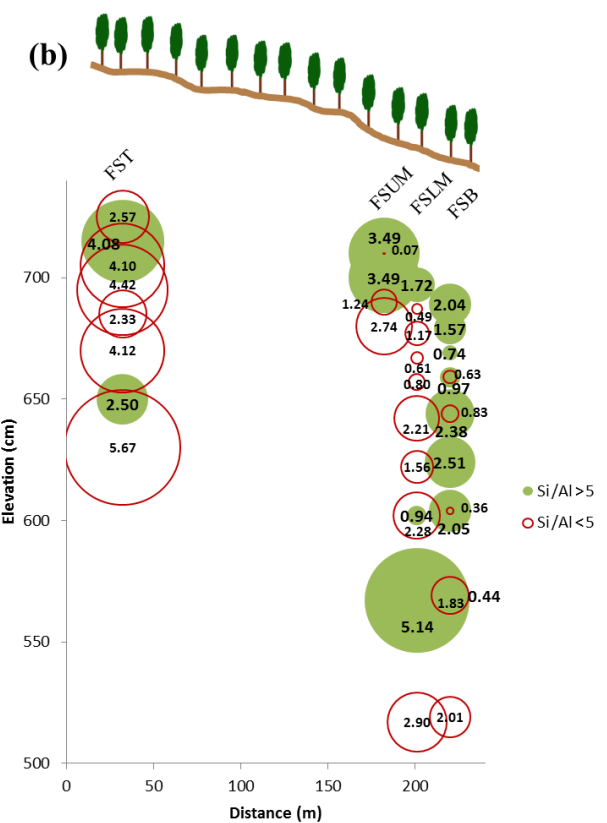

(d)

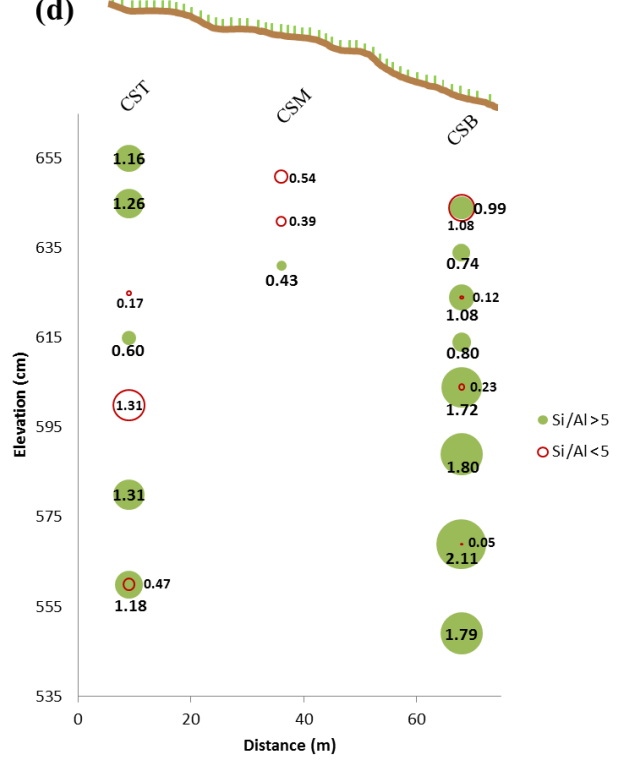

Figure 4. Biogenic and non-biogenic AlkExSi pools $\left(\mathrm{kg} \mathrm{m}^{-2}\right)$ in the studied sites: (a) gentle slope of the forest (FG), (b) steep slope of the forest (FS), (c) gentle slope of the cropland (CG) and (d) steep slope of the cropland (CS). Green bubbles represent biogenic AlkExSi pools. Red empty bubbles represent non-biogenic AlkExSi pools. Labels show values of the pools $\left(\mathrm{kg} \mathrm{m}^{-2}\right)$. Note that the $x$ scales are different.

silica pool from temperate forests in Sweden was close to half our observations (6.7 $\mathrm{kg} \mathrm{m}^{-2}$ in Clymans et al., 2011).

The biogenic AlkExSi pool was not enriched at the lowest position of the gently sloped forest. This suggests that the physical erosion at this site is low. In the steeply sloped forest, higher erosion rate apparently did provoke the physical loss of biogenic AlkExSi, potentially decreasing the amount of Si recycled by the vegetation. BSi is consequently transported to the bottom of the slope before it can dissolve and be recycled by plants, resulting in an accumulation of $\mathrm{BSi}$ at the bottom of the slope ( $\mathrm{AC}$ of $37 \%$ ). However, this ap- parent effect is not statically confirmed probably due to the strong variability of biogenic AlkExSi pools within the top and the bottom pits in the steep-sloped forest. Larger biogenic AlkExSi pools are also found at the lower-middle position, which suggests that the accumulation of eroded material also occurs at the lower-middle slope. Both (lower-middle and bottom) pits together accumulate the $76 \%$ of the total biogenic AlkExSi pool of the slope. These deposition zones could serve as a location for permanent BSi storage.

The average biogenic AlkExSi pool size followed the sequence FS $>$ FG $>$ CG $>$ CS. Overall, cropland gentle and 
steep slopes had 10 and $53 \%$ lower biogenic AlkExSi pool, respectively, compared to well-conserved forest. This loss of biogenic AlkExSi has previously been described in other studies. Vandevenne et al. (2015b) showed similar results for temperate Belgian Luvisols, where croplands showed a decrease in total biogenic AlkExSi of $35 \%$ compared to the temperate forest. Results from Clymans et al. (2011) support the same pattern, showing smaller AlkExSi pools in cultivated systems in Sweden. Our results are apparently in contrast with results from Struyf et al. (2010), who showed a large reduction in DSi export after deforestation in croplands deforested $>250$ years ago. Nevertheless, the absence of a larger decrease in the gently sloped cropland may indicate that deforestation occurred too recently to see such a decrease, only triggered by harvest. Opfergelt et al. (2010) found phytoliths from the previous forested system in croplands of Cameroon deforested in the early 1950s. However, top and bottom positions do not differ statistically between the cropland and its forest counterpart for any of the slopes. The difference relies only on the mid-positions, where erosion is higher (Doetterl et al., 2015), highlighting the importance of erosion as an added factor, as a consequence of the agricultural tillage (Govers et al., 1996).

A depletion of $>50 \%$ is seen at the steep slope of the cropland compared to its forested counterpart. Although it has been shown that an increase in erosion rate occurs after the conversion from forests to croplands (Vanacker et al., 2014) and this may affect both croplands, Montgomery and Brandon (2002) described how the erosion rate depends directly on the slope and stressed the importance of landslides. The consequence is an increase in the accumulation of biogenic AlkExSi pool at the bottom of the steep slope of the cropland (AC of $67 \%$ ).

\subsection{Importance of scales and methods}

The present study clearly shows how deforestation may have a strong impact on the silica cycling in subtropical soils under steep slopes, and potentially also on gentler slopes in the long term. The croplands in earlier studies, e.g., Vandevenne et al. (2015b), had usually been cultivated for more than 200 years, and BSi depletion was explained as a result of long-term cultivation. However, the croplands in the present study were deforested 50 years ago, highlighting how fast the biogenic AlkExSi pool can be depleted from the soil system when physical erosion is high.

Our results confirm the importance of using a continuous extraction to determine BSi pools in soils (Barão et al., 2014). The non-biogenic AlkExSi fractions would have been determined as BSi if conventional alkaline extractions, applying only analyses during the linear phase of the extraction, had been used (i.e., adaptations of the method from DeMaster, 1981). We acknowledge that some difficulties still remain when applying the method we have used. The dissolution in $\mathrm{NaOH}$ does not show a true reactivity within soils: the non- biogenic AlkExSi fractions probably have lower solubility in soils (Ronchi et al., 2015) or water (Unzué-Belmonte et al., 2016) than BSi. Using the Si / Al ratio thresholds described for temperate soils to determine the character of the fractions in a different soil introduces some concerns. Without physical extraction we cannot verify that fractions showing specific ratios (below 5) correspond to the same pedogenic compounds as those found in temperate soils. The method is also unable to distinguish, among the $\mathrm{Si} / \mathrm{Al}>5$ fractions, between phytoliths and opal-A/CT. Under a silica-saturated system, silica can precipitate in amorphous structures called opal-A, that in further transformations could be transformed into opal-CT and finally microquartz (Chadwick et al., 1987; Drees et al., 1989). Opal deposits were identified at more than $1 \mathrm{~m}$ deep layers in temperate pastures (Vandevenne et al., 2015b) and the tropics (Alexandre et al., 1997). Moreover, results from (Saccone et al., 2007) showed that the amounts of easily soluble silica were larger in deeper horizons, agreeing with the possibility of having opal-A at deeper layers in our systems. Despite some concerns, the method used allowed us to identify a new non-biogenic AlkExSi pool which might have been affected by land use and erosion as well.

\subsection{Effects of erosion and land use change on the non-biogenic AlkExSi pool along the toposequence}

The averaged total pool of non-biogenic AlkExSi followed the sequence FS $>$ CG $>$ FG $>$ CS. A study in Belgian Luvisols under long-term cropland management (Vandevenne et al., 2015a) showed a larger non-biogenic AlkExSi pool in the croplands relative to a forested site. The authors explained the result by the fact that the high Si demand from the crops increases the weathering rate of the mineral phases, transforming low-solubility compounds into high-solubility ones (with the caveat that solubility is determined in $\mathrm{NaOH}$ ). A combination of a relatively short time period since deforestation and the increased demand for Si by the crops compared to forest species could thus explain the larger nonbiogenic AlkExSi pool in gently sloping cropland, compared to forests.

However, the non-biogenic AlkExSi pool of the steeply sloping cropland is almost non-existent. As with the biogenic AlkExSi pool, the high Si demand by crops together with the higher erosion rate results in a complete depletion of the nonbiogenic AlkExSi pool in the steeply sloped cropland.

The steeply sloped forest showed a larger non-biogenic AlkExSi pool, mainly accumulated at top and bottom positions (Fig. 4). It is clear that the continuous long-term biogenic AlkExSi deposition at bottom positions (apparent also at the lower-middle position) triggers the formation of new non-biogenic AlkExSi phases that correspond with lower TRB values. Weathering degree has previously been correlated to the amount of pedogenic silica accumulation in sedimentary soils (Kendrick and Graham, 2004). Further, clay 
minerals and $\mathrm{Si}$ adsorbed onto oxides were reported by Delvaux et al. (1989) and Opfergelt et al. (2009), respectively, to be largest at most weathered sites in a study carried out in volcanic soils from Cameroon.

\subsection{Implications}

We show how slope and land use change have strong interacting effects on the distribution of the AlkExSi pool in a subtropical soil. In general, our study agrees well with earlier findings in temperate climates: landscape cultivation diminishes soil BSi stocks. Even though deforestation occurred only 50 years ago, the biogenic AlkExSi pool in the steeply sloped cropland was only $50 \%$ of the pool in steeply sloped forests. In contrast, on the gentle slopes, no similar depletion was observed. This highlights the importance of erosion strength for the rate of depletion. To our knowledge, almost no studies have included slope as a potential factor (Ibrahim and Lal, 2014). It could therefore also be relevant to include erosion rates in studies of $\mathrm{BSi}$ in temperate ecosystems.

The presence of phytoliths from the past in soils helps to reconstruct former vegetation (Kirchholtes et al., 2015; Rovner, 1971). Here, we consider the biogenic Si pool as a single biogeochemical pool that is able to supply readily available DSi for plants. Although the presence of two Si pools within the plant is well documented (Fraysse et al., 2009; Watteau and Villemin, 2001) and different pools may show different solubilities, the higher solubility of phytoliths in soils compared to non-biological solid Si phases has been confirmed by several studies (Fraysse et al., 2006; Lindsay, 1979; Ronchi et al., 2015; Sommer et al., 2013). Moreover, Alexandre et al. (1997) described how $92 \%$ of the BSi in top soil is rapidly recycled, while only $8 \%$ seems to be permanently stored due to a lower turnover.

The silicon and carbon cycles are closely related through the production of phytoliths. A recent study showed a positive relation between soil organic carbon (SOC) and amorphous silica content along a toposequence and along the depth profile (Ibrahim and Lal, 2014). However, a comparison between their results and ours is not possible due to the different methods used to extract the silica fractions. The assumed tight relationship between both elements together with the SOC depletion (reported at $45 \%$ ) after 11-50 years of conversion from forest to cropland (Wei et al., 2014) hints at similar mechanisms behind both observations. Some studies have indicated that silica could act as a "carbon protector" through phytolith formation: carbon is occluded within the phytoliths and remains stored until they dissolve (Song et al., 2014). Although there are different opinions regarding this topic (Santos and Alexandre, 2017) some have suggested that atmospheric carbon sequestration could be enhanced through phytolith production and subsequent burial (Li et al., 2013; Parr et al., 2010; Song et al., 2016).

Our study highlights the accumulation of biogenic AlkExSi at deposition zones in croplands. Very little is known on the potential Si sink associated with such deposition zones, as little research has actually focused on Si biogeochemistry in these zones. Deposition of BSi here could be an important sink for $\mathrm{Si}$ in the long term. As shown earlier in tidal marshes (Struyf et al., 2007), rapid accumulation of BSi can prevent its complete dissolution, resulting in long-term burial and removal from the global biogeochemical Si cycle.

Data availability. Particle size distribution can be found under https://doi.org/10.17632/pcbpbx5x7n.1 (Campforts et al., 2016). Alkaline-extractable fractions are available from https://doi.org/10.17632/r996jnwhtg.1 (Unzué-Belmonte et al., 2017).

\section{The Supplement related to this article is available online at https://doi.org/10.5194/se-8-737-2017-supplement.}

Competing interests. The authors declare that they have no conflict of interest.

Acknowledgements. We thank BELSPO for funding project SOGLO (The soil system under global change, P7/24), all the members of the SOGLO project and the University of Santa Maria for their help during field work in Brazil. Dácil Unzué-Belmonte also thanks the Soil System Sciences Division of the European Geoscience Union (EGU) for awarding her the best Outstanding Student Poster Award at the 2014 EGU Assembly.

Edited by: Miriam Muñoz-Rojas

Reviewed by: two anonymous referees

\section{References}

Alexandre, A., Meunier, J.-D., Colin, F., and Koud, J.-M.: Plant impact on the biogeochemical cycle of silicon and related weathering processes, Geochim. Cosmochim. Ac., 61, 677-682, https://doi.org/10.1016/S0016-7037(97)00001-X, 1997.

Ameijeiras-Mariño, Y.: Changes in soil chemical weathering intensity after forest conversion to cropland: importance of slope geomorphology, in: The response of soil chemical weathering to physical erosion: integrating the impact of forest conversion, edited by: Université catholique de Louvain (UCL), PhD thesis, Belgium, 2017.

Barão, L., Clymans, W., Vandevenne, F., Meire, P., Conley, D. J., and Struyf, E.: Pedogenic and biogenic alkaline-extracted silicon distributions along a temperate land-use gradient, Eur. J. Soil Sci., 65, 693-705, https://doi.org/10.1111/ejss.12161, 2014.

Barão, L., Vandevenne, F., Clymans, W., Frings, P., Ragueneau, O., Meire, P., Conley, D. J., and Struyf, E.: Alkaline-extractable silicon from land to ocean: A challenge for biogenic silicon determination, Limnol. Oceanogr. Methods, 13, 329-344, https://doi.org/10.1002/lom3.10028, 2015. 
Bartoli, F.: Crystallochemistry and surface properties of biogenic opal, J. Soil Sci., 36, 335-350, https://doi.org/10.1111/j.13652389.1985.tb00340.x, 1985.

Blecker, S. W., Mcculley, R. L., Chadwick, O. A., and Kelly, E. F.: Biologic cycling of silica across a grassland bioclimosequence, Global Biogeochem. Cy., 20, 1-11, https://doi.org/10.1029/2006GB002690, 2006.

Campforts, B., Van de Broek, M., Trigalet, S., Schoonejans, J., Robinet, J., Unzué-Belmonte, D., Ameijeiras-Mariño, Y., Vermeire, M. L., and Minella, J.: Soil texture data Brazilian SOGLO field sites, available at: https://doi.org/10.17632/pcbpbx5x7n.1 (last access: 27 June 2017), 2016.

Chadwick, O. A., Hendricks, D. M., and Nettleton, W. D.: Silica in Duric Soils: II. Mineralogy 1, Soil Sci. Soc. Am. J., 51, 982-985, https://doi.org/10.2136/sssaj1987.03615995005100040029x, 1987.

Chao, T. T. and Sanzolone, R. F.: Decomposition techniques, J. Geochemical Explor., 44, 65-106, 1992.

Clymans, W., Struyf, E., Govers, G., Vandevenne, F., and Conley, D. J.: Anthropogenic impact on amorphous silica pools in temperate soils, Biogeosciences, 8, 2281-2293, https://doi.org/10.5194/bg8-2281-2011, 2011.

Clymans, W., Struyf, E., Van den Putte, A., Langhans, C., Wang, Z., and Govers, G.: Amorphous silica mobilization by inter-rill erosion: Insights from rainfall experiments, Earth Surf. Proc. Land., 40, 1171-1181, https://doi.org/10.1002/esp.3707, 2015.

Conley, D. J., Likens, G. E., Buso, D. C., Saccone, L., Bailey, S. W., and Johnson, C. E.: Deforestation causes increased dissolved silicate losses in the Hubbard Brook Experimental Forest, Glob. Chang. Biol., 14, 2548-2554, https://doi.org/10.1111/j.13652486.2008.01667.x, 2008.

Cornelis, J. and Delvaux, B.: Soil processes drive the biological silicon feedback loop, Funct. Ecol., 1, 1298-1310, https://doi.org/10.1111/1365-2435.12704, 2016.

Cornelis, J.-T., Delvaux, B., Georg, R. B., Lucas, Y., Ranger, J., and Opfergelt, S.: Tracing the origin of dissolved silicon transferred from various soil-plant systems towards rivers: a review, Biogeosciences, 8, 89-112, https://doi.org/10.5194/bg-8-89-2011, 2011.

Currie, H. A. and Perry, C. C.: Silica in Plants: Biological, Biochemical and Chemical Studies, Ann. Bot., 100, 1383-1389, https://doi.org/10.1093/aob/mcm247, 2007.

Delvaux, B., Herbillon, A. J., and Vielvoye, L.: Characterization of a weathering sequence of soils derived from volcanic ash in Cameroon. Taxonomic, mineralogical and agronomic implications, Geoderma, 45, 375-388, https://doi.org/10.1016/00167061(89)90017-7, 1989.

DeMaster, D. J.: The supply and accumulation of silica in the marine environment, Geochim. Cosmochim. Ac., 45, 1715-1732, https://doi.org/10.1016/0016-7037(81)90006-5, 1981.

Derry, L. A., Kurtz, A. C., Ziegler, K., and Chadwick, O. A.: Biological control of terrestrial silica cycling and export fluxes to watersheds, Nature, 433, 728-31, https://doi.org/10.1038/nature03299, 2005.

Doetterl, S., Cornelis, J.-T., Six, J., Bodé, S., Opfergelt, S., Boeckx, P., and Van Oost, K.: Soil redistribution and weathering controlling the fate of geochemical and physical carbon stabilization mechanisms in soils of an eroding landscape, Biogeosciences, 12, 1357-1371, https://doi.org/10.5194/bg-12-1357-2015, 2015.
Drees, L. R., Wilding, L. P., Smeck, N. E., and Senkayi, A. L.: Silica in soils: quartz and disorders polymorphs, in Minerals in soil environments, 914-974, Soil Science Society of America, Madison, 1989.

Drever, J. I.: The effect of land plants on weathering rates of silicate minerals, Geochim. Cosmochim. Ac., 58, 2325-2332, https://doi.org/10.1016/0016-7037(94)90013-2, 1994.

Fraysse, F., Pokrovsky, O. S., Schott, J., and Meunier, J.: Surface properties, solubility and dissolution kinetics of bamboo phytoliths, 70, 1939-1951, https://doi.org/10.1016/j.gca.2005.12.025, 2006.

Fraysse, F., Pokrovsky, O. S., Schott, J., and Meunier, J.-D.: Surface chemistry and reactivity of plant phytoliths in aqueous solutions, Chem. Geol., 258, 197-206, https://doi.org/10.1016/j.chemgeo.2008.10.003, 2009.

Govers, G., Quine, T. A., Desmet, P. J. J., and Walling, D. E.: The relative contribution of soil tillage and overland flow erosion to soil redistribution on agricultural land, Earth Surf. Proc. Land., 21, 929-946, https://doi.org/10.1002/(SICI)10969837(199610)21:10<929::AID-ESP631>3.0.CO;2-C, 1996.

Guntzer, F., Keller, C., Poulton, P. R., McGrath, S. P., and Meunier, J. D.: Long-term removal of wheat straw decreases soil amorphous silica at Broadbalk, Rothamsted, Plant Soil, 352, 173-184, https://doi.org/10.1007/s11104-011-0987-4, 2012.

Hall, T. B., Rosillo-Calle, F., Williams, R. H., and Woods, J.: Biomass for energy: supply prospects, in: Renewable Energy: Sources for Fuels and Electricity, edited by: Hall, R. H., Kelly, T. B., Reddy, H., Williams, A. K. N., 593-651, Island Press, Washington DC, 1993.

Herbillon, A. J.: Chemical estimation of weatherable minerals present in the diagnostic horizons of low activity clay soils, in: Proceedings of the 8th International Soil Classification Workshop: Classification, Characterization and Utilization of Oxisols, Part 1, edited by: EMBRAPA, 39-48, Rio de Janeiro, 1986.

Ibrahim, M. A. and Lal, R.: Catena Soil carbon and silicon pools across an un-drained toposequence in central Ohio, Catena, 120, 57-63, https://doi.org/10.1016/j.catena.2014.04.006, 2014.

IUSS Working Group WRB: World Reference Base for Soil Resources 2014, update 2015, International soil classification system for naming soils and creating legends for soil maps, World Soil Resources Reports No. 106, FAO, Rome, 2015.

Jones, L. H. P. and Handreck, K. A.: Effects of Iron and Aluminium Oxides on Silica in Solution in Soils, Nature, 198, 852-853, https://doi.org/10.1038/198852a0, 1963.

Keller, C., Guntzer, F., Barboni, D., Labreuche, J., and Meunier, J. D.: Impact of agriculture on the Si biogeochemical cycle: Input from phytolith studies, C. R. Geosci., 344, 739-746, https://doi.org/10.1016/j.crte.2012.10.004, 2012.

Kelly, E. F., Chadwick, O. A., and Hilinski, T. E.: The effect of plants on mineral weathering, Biogeochemistry, 42, 21-53, https://doi.org/10.1007/978-94-017-2691-7_2, 1998.

Kendrick, K. J. and Graham, R. C.: Pedogenic silica accumulation in chronosequence soils, southern California, Soil Sci. Soc. Am. J., 68, 1295-1303, 2004.

Kirchholtes, R. P. J., van Mourik, J. M., and Johnson, B. R.: Phytoliths as indicators of plant community change: A case study of the reconstruction of the historical extent of the oak savanna in the Willamette Valley Oregon, USA, Catena, 132, 89-96, https://doi.org/10.1016/j.catena.2014.11.004, 2015. 
Koning, E., Epping, E., and Van Raaphorst, W.: Determining Biogenic Silica in Marine Samples by Tracking Silicate and Aluminium Concentrations in Alkaline Leaching Solutions, Aquat. Geochem., 8, 37-67, https://doi.org/10.1023/A:1020318610178, 2002.

Kottek, M., Grieser, J., Beck, C., Rudolf, B., and Rubel, F.: World Map of the Köppen-Geiger climate classification updated, Meteorol. Z., 15, 259-263, https://doi.org/10.1127/09412948/2006/0130, 2006.

Li, Z., Song, Z., Parr, J. F., and Wang, H.: Occluded C in rice phytoliths: implications to biogeochemical carbon sequestration, Plant Soil, 370, 615-623, https://doi.org/10.1007/s11104-0131661-9, 2013.

Lindsay, W. L.: Chemical equilibria in soils, Wiley, New York, available at: http://soils.ifas.ufl.edu/lqma/SEED/CWR6252/ Handout/Chemicalequilibira.pdf (last access: 27 June 2017), 1979.

Meunier, J., Colin, F., and Alarcon, C.: Biogenic silica storage in soils, Geology, 27, 835-838, https://doi.org/10.1130/0091-7613, 1999.

Meunier, J. D., Kirman, S., Strasberg, D., Nicolini, E., Delcher, E., and Keller, C.: The output and bio-cycling of $\mathrm{Si}$ in a tropical rain forest developed on young basalt flows (La Reunion Island), Geoderma, 159, 431-439, https://doi.org/10.1016/j.geoderma.2010.09.010, 2010.

Minella, J. P. G., Walling, D. E., and Merten, G. H.: Establishing a sediment budget for a small agricultural catchment in southern Brazil, to support the development of effective sediment management strategies, J. Hydrol., 519, 2189-2201, https://doi.org/10.1016/j.jhydrol.2014.10.013, 2014.

Montgomery, D. R. and Brandon, M. T.: Topographic controls on erosion rates in tectonically active mountain ranges, Earth Planet. Sci. Lett., 201, 481-489, https://doi.org/10.1016/S0012821X(02)00725-2, 2002.

Opfergelt, S., de Bournonville, G., Cardinal, D., André, L., Delstanche, S., and Delvaux, B.: Impact of soil weathering degree on silicon isotopic fractionation during adsorption onto iron oxides in basaltic ash soils, Cameroon, Geochim. Cosmochim. Ac., 73, 7226-7240, https://doi.org/10.1016/j.gca.2009.09.003, 2009.

Opfergelt, S., Cardinal, D., André, L., Delvigne, C., Bremond, L., and Delvaux, B.: Variations of $\delta 30 \mathrm{Si}$ and $\mathrm{Ge} / \mathrm{Si}$ with weathering and biogenic input in tropical basaltic ash soils under monoculture, Geochim. Cosmochim. Ac., 74, 225-240, https://doi.org/10.1016/j.gca.2009.09.025, 2010.

Parr, J., Sullivan, L., Chen, B., Ye, G., and Zheng, W.: Carbon bio-sequestration within the phytoliths of economic bamboo species, Glob. Chang. Biol., 16, 2661-2667, https://doi.org/10.1111/j.1365-2486.2009.02118.x, 2010.

Piperno, D. R.: Phytoliths: A Comprehensive Guide for Archaeologists and Paleoecologists, Altamira Press, San Diego, 2006.

Robert, M. and Tessier, D.: Méthode de préparation des argiles des sols pour des études minéralogiques, Ann. Agron., 25, 859-882, 1974.

Ronchi, B., Barão, L., Clymans, W., Vandevenne, F., Batelaan, O., Govers, G., Struyf, E., and Dassargues, A.: Factors controlling Si export from soils: A soil column approach, Catena, 133, 85-96, https://doi.org/10.1016/j.catena.2015.05.007, 2015.
Rovner, I.: Potential of opal phytoliths for use in paleoecological reconstruction, Quat. Res., 1, 343-359, https://doi.org/10.1016/0033-5894(71)90070-6, 1971.

Saccone, L., Conley, D. J., Koning, E., Sauer, D., Sommer, M., Kaczorek, D., Blecker, S. W., and Kelly, E. F.: Assessing the extraction and quantification of amorphous silica in soils of forest and grassland ecosystems, Eur. J. Soil Sci., 58, 1446-1459, https://doi.org/10.1111/j.1365-2389.2007.00949.x, 2007.

Santos, G. M. and Alexandre, A.: Earth-Science Reviews The phytolith carbon sequestration concept: Fact or fiction? A comment on "Occurrence, turnover and carbon sequestration potential of phytoliths in terrestrial ecosystems by Song et al. https://doi.org/10.1016/j.earscirev.2016.04.007”, Earth Sci. Rev., 164, 251-255, https://doi.org/10.1016/j.earscirev.2016.11.005, 2017.

Sauer, D., Saccone, L., Conley, D. J., Herrmann, L., and Sommer, M.: Review of methodologies for extracting plant-available and amorphous Si from soils and aquatic sediments, Biogeochemistry, 80, 89-108, https://doi.org/10.1007/s10533-005-5879-3, 2006.

Smis, A., Van Damme, S., Struyf, E., Clymans, W., Van Wesemael, B., Frot, E., Vandevenne, F., Van Hoestenberghe, T., Govers, G., and Meire, P.: A trade-off between dissolved and amorphous silica transport during peak flow events (Scheldt river basin, Belgium): Impacts of precipitation intensity on terrestrial $\mathrm{Si}$ dynamics in strongly cultivated catchments, Biogeochemistry, 106, 475-487, https://doi.org/10.1007/s10533-010-9527-1, 2011.

Sommer, M., Kaczorek, D., Kuzyakov, Y., and Breuer, J.: Silicon pools and fluxes in soils and landscapes - a review, J. Plant Nutr. Soil Sci., 169, 310-329, https://doi.org/10.1002/jpln.200521981, 2006.

Sommer, M., Jochheim, H., Höhn, A., Breuer, J., Zagorski, Z., Busse, J., Barkusky, D., Meier, K., Puppe, D., Wanner, M., and Kaczorek, D.: Si cycling in a forest biogeosystem - the importance of transient state biogenic Si pools, Biogeosciences, 10, 4991-5007, https://doi.org/10.5194/bg-10-4991-2013, 2013.

Song, Z., Wang, H., Strong, P. J., Li, Z., and Jiang, P.: Plant impact on the coupled terrestrial biogeochemical cycles of silicon and carbon: Implications for biogeochemical carbon sequestration, Earth-Sci. Rev., 115, 319-331, https://doi.org/10.1016/j.earscirev.2012.09.006, 2012.

Song, Z., Müller, K., and Wang, H.: Biogeochemical silicon cycle and carbon sequestration in agricultural ecosystems, Earth-Sci. Rev., 139, 268-278, https://doi.org/10.1016/j.earscirev.2014.09.009, 2014.

Song, Z., McGrouther, K., and Wang, H.: Occurrence, turnover and carbon sequestration potential of phytoliths in terrestrial ecosystems, Earth-Sci. Rev., 158, 19-30, https://doi.org/10.1016/j.earscirev.2016.04.007, 2016.

Struyf, E. and Conley, D. J.: Emerging understanding of the ecosystem silica filter, Biogeochemistry, 107, 9-18, https://doi.org/10.1007/s10533-011-9590-2, 2012.

Struyf, E., Temmerman, S., and Meire, P.: Dynamics of biogenic $\mathrm{Si}$ in freshwater tidal marshes: Si regeneration and retention in marsh sediments (Scheldt estuary), Biogeochemistry, 82, 41-53, https://doi.org/10.1007/s10533-006-9051-5, 2007.

Struyf, E., Smis, A., Van Damme, S., Garnier, J., Govers, G., Van Wesemael, B., Conley, D. J., Batelaan, O., Frot, E., Clymans, W., Vandevenne, F., Lancelot, C., Goos, P., and Meire, P.: Historical 
land use change has lowered terrestrial silica mobilization, Nat. Commun., 1, 129, https://doi.org/10.1038/ncomms1128, 2010.

Uehara, G. and Gillman, G.: The Mineralogy, Chemistry, and Physics of Tropical Soils With Variable Charge Clays, West View Press, Boulder, CO, USA, 1981.

Unzué-Belmonte, D., Struyf, E., Clymans, W., Tischer, A., Potthast, K., Bremer, M., Meire, P., and Schaller, J.: Fire enhances solubility of biogenic silica, Sci. Total Environ., 572, 1289-1296, https://doi.org/10.1016/j.scitotenv.2015.12.085, 2016.

Unzué-Belmonte, D., Ameijeiras-Mariño, Y., Trigalet, S., Schoonejans, J., Campforts, B., Van de Broek, M., Robinet, J., and Minella, J.: Alkaline Extractable Silica - SOGLO Project, available at: https://doi.org/10.17632/r996jnwhtg.1, last access: 27 June 2017.

Vanacker, V., Bellin, N., Molina, A., and Kubik, P. W.: Erosion regulation as a function of human disturbances to vegetation cover: a conceptual model, Landsc. Ecol, 29, 293-309, https://doi.org/10.1007/s10980-013-9956-z, 2014.

Van Cappellen, P.: Biomineralization and global biogeochemical cycles, Rev. Mineral. Geochemistry, 54, 357-381, https://doi.org/10.2113/0540357, 2003.

Vandevenne, F., Struyf, E., Clymans, W., and Meire, P.: Agricultural silica harvest: have humans created a new loop in the global silica cycle?, Front. Ecol. Environ., 10, 243-248, https://doi.org/10.1890/110046, 2012.
Vandevenne, F. I., Barão, L., Ronchi, B., Govers, G., Meire, P., Kelly, E. F., and Struyf, E.: Silicon pools in human impacted soils of temperate zones, Global Biogeochem. Cy., 29, 14391450, https://doi.org/10.1002/2014GB005049, $2015 \mathrm{a}$.

Vandevenne, F. I., Delvaux, C., Hughes, H. J., André, L., Ronchi, B., Clymans, W., Barão, L., Cornelis, J.-T., Govers, G., Meire, P., and Struyf, E.: Landscape cultivation alters $\delta 30 \mathrm{Si}$ signature in terrestrial ecosystems, Sci. Rep., 5, 7732, https://doi.org/10.1038/srep07732, 2015b.

Von Braun, J.: The world food situation: new driving forces and required actions, Food Policy Reports 18, International Food Policy Research Institute, Washington DC, 2007.

Watteau, F. and Villemin, G.: Ultrastructural study of the biogeochemical cycle of silicon in the soil and litter of a temperate forest, Eur. J. Soil Sci., 52, 385-396, https://doi.org/10.1046/j.13652389.2001.00391.x, 2001.

Wei, X., Shao, M., Gale, W., and Li, L.: Global pattern of soil carbon losses due to the conversion of forests to agricultural land, Sci. Rep., 1, 6-11, https://doi.org/10.1038/srep04062, 2014. 